\title{
Development of Topic Management Skills in Conversation of School-Aged Children
}

\author{
Yun Jeong Park ${ }^{\mathrm{a}}$, Jieun Choi ${ }^{\mathrm{a}}$, YoonKyoung Lee ${ }^{\mathrm{b}}$ \\ ${ }^{a}$ Department of Speech-Language Pathology and Audiology, Graduate School of Hallym University, Chuncheon, Korea \\ ${ }^{b}$ Division of Speech Pathology and Audiology, Hallym University, Chuncheon, Korea
}

Correspondence: YoonKyoung Lee, $\mathrm{PhD}$ Division of Speech Pathology and Audiology, Hallym University, 1 Hallimdaehak-gil, Chuncheon 24252, Korea

Tel: +82-33-248-2219

Fax: +82-33-256-3420

E-mail: ylee@hallym.ac.kr

Received: January 5, 2017

Revised: February 22, 2017

Accepted: February 28, 2017

This work is based on a partial data from the first author's master thesis.

\begin{abstract}
Objectives: Conversational skills play an important role in social aspects such as the peer relationships and academic achievement of school-aged children. The purpose of this study was to investigate developmental differences according to grade for primary school students in the 1st, 3rd, and 5th grade. Methods: The participants were a total of 30 children, 10 children per grade. Conversation samples were collected individually by the examiner according to procedure of Hallym Conversation \& Pragmatic Assessment Protocol. In terms of engagement indicator, the frequency of turn-taking, frequency of utterances per turn. Additionally, in terms of topic indicator, the total number of topics, frequency of turn per topic, rates of maintenance and rates of change were measured. Results: The results were as follows: in engagement indicator, significant difference was observed in the frequency of utterances per turn. In topic indicator, there were significant differences in the total number of topics, frequency of turn per topic, rates of maintenance, and rates of change. Conclusion: The results of this study showed that as school-aged children's grade increased they were able to converse over a given topic with more consistency. These results help elucidate the development of conversation in elementary school-children and can be used as materials for the assessment and intervention of children with disabilities.
\end{abstract}

Keywords: School-aged, Conversational development, Topic management, Topic manipulation
다른 사람과 원활한 관계를 형성하기 위해서는 다른 사람과 의 사소통을 하는 것이 매우 중요하다. 대부분의 사람들이 일상생활 속에서 대화를 통해 의사소통하게 되는데, 대화는 2 명 이상의 사 람들이 공통된 화제로 말을 서로 주고받으며 이어가는 것을 말한 다(Heo \& Lee, 2012). 사람들은 대화를 통해 정보를 얻거나 전달하 고, 감정을 공유하며, 중요한 인간관계를 맺어나간다. 성공적인 대 화를 위해서는 대화차례를 주고받는 기술과 대화의 화제를 다루는 능력이 특히 중요하다(Choi \& Lee, 2013; Heo \& Lee, 2012; Prutting \& Kittchner, 1987).

대화차례 주고받기는 화자와 청자가 서로 번갈아가면서 말하는 것으로 대화의 기본을 이룬다. 대화가 원활하게 이루어지기 위해서 는 자신의 대화차례를 너무 오래 독점하지 않아야 하며, 상대방의 말을 방해하거나 대화 흐름이 끊어지지 않도록주고받는 기술이 필
요하다(Owens, 2004). 대화차례를 주고받는 것은 상호작용을 이어 나가기 위한 행동들로 화제를 연속적으로 주고받으며 이루어진다 (Stech, 1982). 대화에서 화제는 '화자가 말하고 있는 관심사'를 말 하며, 대화는 화제가 연속됨으로써 이어나가게 된다(Owens, 2004). 따라서 원활한 대화를 위해서는 상대방과의 상호작용 속에서 대화 차례 내에 하나의 화제를 연속적으로 이어나가는 능력들이 중요하 다. 대화 참여자 간에 공통된 화제를 효율적으로 운용하는 능력을 화제관리능력이라고 하는데(Brinton \& Fujiki, 1984), 이러한 능력 은 응집력 있게 대화를 이어나갈 수 있도록 하며, 문맥과 상황에 맞 게 화제를 개시하거나 유지하는 능력이 요구된다(Mentis, 1994).

이러한 대화 능력은 생애초기부터 서서히 발달되기 시작하나 실 질적으로는 학령기 시기가 되어야 정교하게 발달하기 시작한다. 언 어 이전기 영유아들은 양육자와의 상호작용을 통해 대화차례를 
주고받는 대화의 원형이 형성된다(Rosenthal, 1982). 이 시기의 영 유아들은 주로 몸짓, 울음, 발성과 같은 비구어적 형태로 대화차례 를 번갈아가며 주고받으며 성인의 개시에 반응할 수 있지만, 하나 의 화제에 대해서 화제를 관리하는 측면은 제한된다(Foster, 1985). 유아기에 접어들면서 대화 화제에 적절히 반응하고 유지해 나가지 만, 하나의 화제로 이야기하는 발화가 비교적 짧고(Schober-Peterson \& Johnson, 1989), 대화 상대자의 말에 새로운 정보를 추가하 지 않고 반복하여 유지하는 경향(Keenan \& Klein, 1975)을 보이는 등 여전히 화제관리능력은 부족하다.

학령기로 갈수록 대화 능력이 점차 향상됨에 따라 특정 화제를 중심으로 대화를 주고받는 길이가 길어지고, 화제를 다루는 능력 또한 학령기 저학년에서 고학년으로 가면서 점진적으로 발달하게 된다(Nippold, 2007). 저학년 아동들은 대화 내에서 화제를 빠르게 전환하며 다양한 화제를 제시하고, 간단한 예/아니오 대답, 형식을 변경하여 대답함으로써 화제를 유지해나간다. 고학년 아동들은 하 나의 화제로 더 심도있는 대화를 이어나가게 되고, 새로운 정보를 첨가하거나 확장하며 대화의 화제를 길게 유지해나간다(Brinton \& Fujiki, 1984; Mentis, 1994; Schober-Peterson \& Johnson, 1993). Brinton과 Fujiki (1984)는 학령기 대화 발달을 확인하기 위해 5, 9 세 대화와 성인의 대화를 살펴보았는데, 연령이 높아질수록 새로 운 화제를 소개하는 빈도는 감소하는 반면 화제를 유지하는 길이 가 길어진다는 것을 발견하였으며, Sehley와 Snow (1992) 또한 2-5 학년 아동을 대상으로 연령이 증가할수록 화제를 유지하는 비율 이 증가한다고 보고하였다. 이처럼 학령기로 갈수록 상대방과 적절 하게 대화차례를 주고받으며 같은 화제로 대화를 유지해 나가는 능 력들이 점차 발달하게 된다(Brinton \& Fujiki, 1984; Dorval, Eckerman, \& Ervin-Tripp, 1984; Hoff, 2009).

학령기 아동의 대화는 또래 관계 형성 및 학업 성취와 같은 사회 적 능력에 중요한 역할을 한다는 보고에 따라 그 중요성이 강조되 고 있다(Owens, 2004). 대화는 인지적, 언어적, 화용적 능력이 요구 되며(Nippold, 2007), 화제관리능력은 화용 능력의 결함을 확인하 고 설명하는데 중요한 역할을 한다(Prutting \& Kittchner, 1987). 국 내에서는 주로 대화 특성을 단순언어장애(Lee \& Kim, 2001), 언어 학습부진(Heo \& Lee, 2012), 지적장애(Choi \& Jeon, 2003; Hong \& Lee, 2016), 자폐스펙트럼장애(Choi \& Lee, 2013, 2015), 주의력결핍 과잉행동장애(Kim \& Lee, 2007), 인공와우이식(CI) 아동(Hong, $\mathrm{Heo}, \& \mathrm{Lee}, 2012)$ 과 같이 주로 언어 및 의사소통에 어려움을 갖는 아동들을 대상으로 연구되어왔다. 대체로 대화차례 주고받기와 화 제관리능력을 중심으로 살펴보았는데, 특히 주의력결핍과잉행동 장애의 경우 대화차례 지키기에 어려움을 보였지만, 대부분의 장애
아동들은 대화차례를 지키더라도 화제를 효과적으로 다루는 화제 관리능력이 부족하여 수동적으로 대화에 참여하거나 대화 화제에 서 벗어난 발화를 많이 산출한다고 보고되었다. 언어장애 및 발달 장애 아동들의 지연되거나 일탈된 대화 특성들을 평가하고 중재하 는 것도 중요하지만, 일반아동의 대화 발달 연구는 일반적인 발달 적 경향성을 제시하여 전형적·비전형적인 패턴을 확인하기 위한 기초적인 자료로 제시될 수 있으므로 대화 능력의 발달적 양상을 살펴보는 것이 무엇보다 중요하다.

대화 발달 연구의 중요성이 강조됨과 동시에 일반 발달 연구는 장애 아동들의 대화 특징을 이해하는데 도움이 될 수 있음에도 불 구하고 일반아동을 대상으로 대화 발달을 살펴본 연구는 많이 이 루어지지 않았다. 대화 발달을 살펴본 국외의 선행연구들(Baines \& Howe, 2010; Brinton \& Fujiki, 1984; Sehley \& Snow, 1992)은 대 부분 오래 전에 진행된 연구이며, 최근 연구라 하더라도 대화 능력 은 문화적 배경 및 언어에 따라 영향을 받을 가능성이 있기 때문에 문화적 배경을 고려하여 다양한 언어적 환경에서 이루어져야 할 필 요성이 있다(Sehley \& Snow, 1992). 따라서 국내 아동을 대상으로 대화 발달을 살펴보는 것이 필요할 것이다. 국내에서는 학령전기의 유치원 아동을 대상으로 화제관리능력을 살펴보기는 했지만(Park, 2001), 초등학생의 대화 능력을 살펴본 연구는 찾아보기 힘든 실정 이다. 학령기 아동들의 대화 능력은 또래 관계 형성 및 학업 성취에 매우 중요하다. 따라서 본 연구는 국내의 초등학생 1 학년, 3 학년, 5 학년 아동들을 대상으로 대화 발달을 살펴보고자 하였다. 또한 대 화는 대화 상대자에 따라 영향을 많이 받기 때문에 자연스러운 대 화를 유지하되 대화 상대자 요인을 최대한 통제한 대화 유도 절차 를 활용하여 대화 샘플을 수집하고, 정해진 프로토콜 안에서 대화 에 참여하고 주도하는 정도와 화제를 관리하는 능력이 학년에 따 라 어떻게 발달하는지를 알아보고자 하였다.

\section{연구 방법}

\section{연구 대상}

본 연구의 대상은 강원 및 경기지역 초등학교에 재학 중인 1 학년, 3 학년, 5 학년으로 각 집단당 10 명씩, 총 30 명이다. 학령전기에서 학 령기로 넘어가는 시기인 1학년을 기준으로 하였으며, 발달적 경향 을 살펴보기 위해 2년의 간격을 둔 1학년, 3 학년, 5 학년 아동을 대 상으로 하였다. 아동들은 모두 (1) 주 양육자에 의해 신체, 운동, 감 각, 정서 등 발달이 정상적으로 이루어졌다고 보고되었으며, (2) 학 령기 아동언어검사(Language Scale for School-aged Children, LSSC; Lee, Heo, \& Jhang, 2014)에서 수용언어 능력 및 표현언어 능력과 
Table 1. Participants' information

\begin{tabular}{lccr}
\hline & $\begin{array}{c}\text { 1st grade } \\
(\mathrm{N}=10)\end{array}$ & $\begin{array}{c}\text { 3rd grade } \\
(\mathrm{N}=10)\end{array}$ & $\begin{array}{c}\text { 5th grade } \\
(\mathrm{N}=10)\end{array}$ \\
\hline $\mathrm{CA}(\mathrm{mo})$ & $87.9(3.67)$ & $112.2(3.59)$ & $137.6(2.64)$ \\
LSSC USP converted score & $14.6(3.17)$ & $14.3(1.64)$ & $12.6(2.34)$ \\
LSSC GEJ converted score & $13.0(1.49)$ & $12.9(.88)$ & $12.3(1.06)$ \\
LSSC GER converted score & $14.8(2.70)$ & $12.3(1.06)$ & $13.0(1.76)$ \\
\hline
\end{tabular}

Values are presented as mean (SD).

$C A=$ chronological age; $L S S C=$ Language Scale for School-aged Children (Lee, Heo, \& Jhang, 2014); USP=understanding spoken paragraph; GEJ=grammatical error judgement; $\mathrm{GER}=$ grammatical error revision.

높은 상관을 보인 ‘단락듣기 이해’문항과 ‘문법 판단 및 수정’문항 검사 결과 각 항목에서 환산점수 10 점 내외(-1 SD 이상)에 있는 아 동들로 선정하였다. LSSC의 환산점수는 각 항목의 원점수를 평균 10 , 표준편차 3 으로 변환한 점수이다. 모든 아동의 부모님들에게 검사 실시 전 부모 동의서를 얻은 후, 모든 절차를 진행하였다. 연구 대상의 기본정보는 Table 1 과 같다.

\section{자료 수집 도구 및 절차}

아동의 대화 자료는 연구자와 1:1로 조용한 방에서 한림 대화. 화용 평가 프로토콜(Lee \& Choi, 2017) 중 대화 유도 절차를 사용 하여 수집하였다. 대화 유도 절차는 Evans와 Craig (1992) 그리고 Brinton, Fujiki와 Powell (1997)의 연구에 기초하여 개발되었으며, Heo와 Lee (2012), Choi와 Lee (2013, 2015), Hong과 Lee (2016)의 연구를 통해 절차가 수정 및 보완되었다. 대화 능력은 대화 상대자 에 영향을 받기 때문에 대화 유도 절차에서 최대한 대화 상대자 요 인을 통제하였다. 아동에게 익숙한 '가정생활, 학교생활, 기타/친구' 를 대화 화제로 선정하였으며, '가정생활', '학교생활' 과 관련된 사 진을 각각 4 개씩 준비하여 봉투 안에 담아두었고, '기타/친구' 는 사 진 자료 없이 구어로 화제를 제시하였다. 각각의 화제별로 3 가지의 소주제 질문을 사전에 준비하였으며, 소주제는 '가정생활'에 주말, 명절, 생일, '학교생활'에는 점심/쉬는 시간, 방과후, 현장학습, '기 타/친구'에는 놀이, 좋아하는 것, TV프로그램이었다. 사진의 크기 는 가로 $110 \mathrm{~mm}$, 세로 $85 \mathrm{~mm}$ 였다. 대화는 다음과 같은 절차로 진 행하였다.

먼저 연구자는 아동에게 진행 절차를 설명해주었다. 아동이 절 차를 숙지하였다고 판단되면, 아동에게 2 개의 봉투 중 하나를 선택 하게 하였고, 아동이 선택한 봉투의 사진을 아동의 앞에 펼쳐주며 살펴보게 한 후, 화제를 개시할 수 있는 기회를 제공하였다. 아동이 자발적으로 개시하는 경우 대화를 이어나갔으며, 연구자가 미리 정 해놓은 3 개의 소주제 중 자발적으로 개시하지 않은 내용의 경우에
는 관련된 질문을 제공하였다. 아동이 2-3초 내에 먼저 발화를 시 작하지 않을 경우에는 "OO아, 가정생활은 어때?" 또는 "학교 생활 은 어때?”라고 해당 화제를 언급해 주었다. 언급해주어도 반응이 없는 경우, "학교에서 점심 시간이나 쉬는 시간에는 뭐해?", "주말 에는 가족들과 뭐하면서 보내?"와 같은 화제와 관련된 소주제 질 문을 하였다.

모든 아동에게 연구자는 대화상대자 요인을 최소화하되 자연스 러운 대화를 유지하기 위해 아동의 대화차례가 끝나면 새로운 질 문이나 내용을 첨가하지 않고 아동의 이전 발화의 말을 반복해주 며 중립적인 반응을 해주었다. 2-3초 이후에도 발화를 이어나가지 않는 경우 “그리고?", “또?”와 같이 촉진해주며 대화를 이어나가도 록 하였다. 각 화제에서 아동이 끝맺는 말, 할 말이 없다는 행동(시 선, 미소, 무반응 등)을 보이면 다음 화제를 선택하게 한 후, 앞의 절 차로 대화를 진행하였다.

\section{자료 전사 및 자료 분석}

대화 자료는 3 가지 큰 화제로 대화를 충실하게 완료한 아동의 자 료만을 선정하였으며, 아동들의 대화 자료는 평균 12 분 40 초였다. 녹음 및 녹화한 내용을 바탕으로 Heo와 Lee (2012)의 대화차례 분 석 기준(Appendix 1)에 따라 대화차례를 기반으로 하여 일주일 이 내에 전사하였다. 발화는 Kim (1997)의 발화 구분 원칙에 따라 전 사되었다. 대화 자료는 크게 대화의 참여 지표와 화제 지표로 나누 어 측정하였다. 각각에 대한 정의 및 측정방법은 다음과 같다.

\section{대화 참여 지표}

동일한 절차 안에서 얼마나 대화에 참여하고 주도하였는지 확인 하기 위해 대화차례 주고받기 빈도와 대화차례 당 발화수로 나누어 측정하였다.

대화차례 주고받기 빈도

하나의 대화차례는 화자가 말을 시작하여 대화 상대자가 말을 시작하기 전까지의 하나 이상의 모든 발화로, 대화차례 주고받기 빈도는 아동이 대화에 참여한 양을 반영한다. 대화 절차를 완료하 는 동안에 아동이 총 산출한 대화차례 빈도로 측정하였다.

\section{대화차례당 발화수}

아동이 한 번의 대화차례에서 산출하는 발화를 말하며, 자신의 대화차례에서 얼마나 많은 이야기를 하는지를 반영한다. 아동의 발화수를 전체 대화차례 빈도로 나누어서 측정하였다. 
대화 화제 지표

화제란 화자가 발화를 통해 제공한 주요 정보로(Owens, 2004), Schober-Peterson과 Johnson (1993)의 기준으로 화제를 분류하였 으며(Appendix 2), Choi와 Lee (2013)의 정의에 따라 화제관리능력 을 분류하였다(Appendix 3). 아동의 화제관리능력을 확인하기 위 해 전체 화제 수, 화제 유지 능력(화제당 대화차례 빈도, 화제 유지 비율), 화제 변경 비율로 나누어 측정하였다.

화제수

화제 수는 제시된 큰 화제 안에서 얼마나 다양한 화제를 다루는 지 확인하는 것으로, 수집된 대화 샘플에서 연구자와 아동이 함께 도입한 모든 화제를 빈도로 측정하였다.

\section{화제 유지 능력}

화제 유지는 이전 대화차례에서 개시된 화제와 관련된 내용을 반복하고, 간단한 정보 또는 세밀한 의미를 추가하며 대화차례를 이어나가는 경우이며, 동일한 어휘나 동일한 주제(theme)로 연결하 거나 동일한 개념 및 구성요소들로 이루어진 경우를 말한다. 화제 유지는 화제당 대화차례 빈도와 화제 유지 비율의 두 가지로 측정 하였다. 화제당 대화차례 빈도는 아동이 총 산출한 대화차례 빈도 를 수집된 대화 샘플에서 다루어진 모든 화제 수로 나누어 측정하 였다. 화제 유지 비율은 아동의 대화차례에서 화제 유지가 차지하 는 비율로 산출하였다.

화제 변경 비율

화제 변경은 대화를 이어나가는 도중 이전 대화차례의 화제와 연결되지 않거나 자신의 이전 발화에서 새로운 화제로 대화 화제가 바뀌는 경우를 말하며, 대화차례에서 화제 변경이 차지하는 비율 로 산출하였다.

\section{신뢰도}

자료 분석에 대한 신뢰도를 검증하기 위해 제 2 연구자로 언어병 리학을 전공하는 석사과정 대학원생 1 명을 선정하였다. 제 2 연구자 에게 검사 절차, 기록 방법, 분석 방법을 자세히 설명한 후 분석에
사용되지 않는 아동 1 명의 대화 자료로 연습하여 불일치된 부분에 대해 연구자와 제 2 연구자가 논의한 후 합의하여 의견을 조정하였 다. 이후 무작위로 추출한 자료의 $10 \%$ 를 독립적으로 분석하도록 하여 신뢰도를 측정하였다. 신뢰도를 측정하는 방법은 연구자와 제 2 연구자가 일치한 반응의 수를 일치한 반응의 수와 일치하지 않 은 반응의 수로 합하여 나눈 후 100 을 곱하여 산출하였다. 그 결과 신뢰 수준은 $94 \%$ 로 측정되었다.

\section{통계 처리}

자료의 통계처리는 화제관리능력의 학년 집단 간 차이가 있는지 알아보기 위해 일원배치 분산분석(one-way ANOVA)을 사용하여 분석하였고, Tukey 사후분석을 실시하여 어떠한 집단에서 유의한 차이가 있었는지 살펴보았다. 통계분석에 사용한 프로그램은 SPSS ver. 22 였다.

\section{연구 결과}

\section{학년에 따른 대화 참여 지표 발달}

1 학년, 3 학년, 5 학년 집단의 대화 참여 지표 발달을 확인하기 위 해 대화차례 주고받기 빈도와 대화차례당 발화 수를 비교한 결과 는 Table 2와같다.

대화차례 주고받기 빈도에서는 학년 집단 간 유의한 차이를 보이 지 않았지만, 대화차례당 발화 수에서는 집단 간 유의미한 차이를 보였다 $\left(F_{(2,27)}=4.556, p<.05\right)$. 대화차례당 발화 빈도의 집단 차이 는 5 학년 집단과 1 학년 집단 간의 차이로, 5 학년 집단이 1 학년 집단 에 비해 대화차례당 발화수가 많았다.

\section{학년에 따른 대화 화제 지표 발달}

1 학년, 3 학년, 5 학년 집단의 대화 화제 지표 발달을 확인하기 위 해 화제 수, 화제 유지 능력(화제당 대화차례 빈도, 화제 유지 비율), 화제 변경 비율을 비교한 결과는 Table 3 과 같다.

화제 수 $\left(F_{(2,27)}=10.151, p<.01\right)$ 와 화제당 대화차례 빈도 $\left(F_{(2,27)}=\right.$ $10.445, p<.001)$, 화제 유지 비율 $\left(F_{(2,27)}=6.738, p<.01\right)$, 화제 변경 비율 $\left(F_{(2,27)}=9.06, p<.01\right)$ 모두 학년 집단 간 유의미한 차이를 보였

Table 2. Comparison of frequency of turn-taking and number of utterance per turn among the three groups

\begin{tabular}{lccccc}
\hline & 1 st grade & 3rd grade & 5th grade & $F$ & Tukey post-hoc \\
\hline Frequency of turn-taking & $54.08(10.22)$ & $60.20(10.63)$ & $51.60(3.20)$ & 2.489 & \\
Number of utterance per turn & $1.01(.24)$ & $1.16(.15)$ & $1.23(.74)$ & $4.556^{*}$ & 5 th> 1 st \\
\hline
\end{tabular}

Values are presented as mean (SD).

${ }^{*} p<.05$. 
Table 3. Comparison of number of topic and turn per topic among the three groups

\begin{tabular}{|c|c|c|c|c|c|}
\hline & 1st grade & 3rd grade & 5th grade & $F$ & Tukey post-hoc \\
\hline Number of topic & $19.5(4.62)$ & $17.2(3.42)$ & $12.5(2.12)$ & $10.151^{* *}$ & 1st, 3rd $>5$ th \\
\hline $\begin{array}{l}\text { Topic maintenance } \\
\text { Turn per topic } \\
\% \text { of topic maintenance }\end{array}$ & $\begin{array}{c}3.17(.53) \\
82.91(7.12)\end{array}$ & $\begin{array}{c}3.78(.49) \\
85.62(6.68)\end{array}$ & $\begin{array}{r}4.79(1.19) \\
92.59(3.84)\end{array}$ & $\begin{array}{c}10.445^{* * *} \\
6.783^{* *}\end{array}$ & $\begin{array}{l}1 \mathrm{st}, 3 \mathrm{rd}<5 \text { th } \\
1 \mathrm{st}, 3 \mathrm{rd}<5 \text { th }\end{array}$ \\
\hline$\%$ of topic change & $14.76(6.26)$ & $10.88(6.0)$ & $4.47(3.77)$ & $9.06^{* *}$ & $1 \mathrm{st}, 3 \mathrm{rd}>5 \mathrm{th}$ \\
\hline
\end{tabular}

Values are presented as mean (SD).

${ }^{* *} p<.01,{ }^{* * *} p<.001$.

다. 화제 수와 화제당 대화차례 빈도, 화제 유지 비율, 화제 변경 비 율의 집단 차이는 5 학년 집단과 1 학년 집단, 3 학년 집단 간의 유의 한 차이로 인한 것으로 나타났다. 즉, 5 학년 집단은 1 학년 집단과 3 학년 집단에 비해 화제당 대화차례 빈도와 화제 유지 비율이 높은 반면 화제 수와화제 변경 비율은 적었다.

\section{논의 및 결론}

본 연구는 학령기 아동의 대화 능력을 살펴보고자 하였다. 이를 위해 국내의 초등학생 1 학년, 3 학년, 5 학년 아동들을 대상으로 대 화 상대자 요인을 최소화하며 자연스러운 대화를 유지하는 방법으 로 대화 샘플을 수집하였고, 정해진 프로토콜 안에서 대화에 참여 하고 주도하는 정도와 화제를 관리하는 능력이 학년에 따라 어떻 게 발달하는지를 알아보고자 하였다.

먼저 대화에 참여하고 주도하는 정도를 양적으로 살펴보기 위해 서, 대화차례 주고받기의 빈도와 대화차례당 발화 수를 분석하였 다. 대화차례 주고받기 빈도는 정해진 절차 내에서 아동이 산출한 대화차례의 총 수를 말하며, 빈도가 높을수록 주도적으로 대화를 이끈다는 것을 반영한다. 하지만 대화차례 주고받기 빈도만으로 아동의 대화 참여와 주도 정도를 확인하기 어렵기 때문에 본 연구 에서는 대화차례당 발화 수를 함께 고려하여 살펴보았다. 그 결과 대화차례 주고받기 빈도는 학년 집단 간 유의미한 차이를 보이지 않은 반면, 대화차례당 발화 수에서는 학년 집단 간 유의한 차이를 보였다. 이는 학년이 높아질수록 대화차례 주고받기 빈도는 증가하 지 않지만 자신의 대화차례에서 더 많은 발화를 산출하며 이야기 한다는 것을 의미한다. 자신의 대화차례에서 더 많은 발화를 산출 하는 것은 언어능력의 향상으로 인한 가능성이 있다. 이러한 가능 성은 언어장애 아동을 대상으로 실시한 연구를 통해 확인할 수 있 다. Lee와 Kim (2001)은 단순언어장애 아동이 일반아동에 비해 대 화차례당 발화 수가 유의하게 적었다고 보고하였으며, 지적장애 (Hong \& Lee, 2016), 언어학습부진(Heo \& Lee, 2012) 아동의 경우 에도 대화차례당 발화 수가 일반아동에 비해 유의하게 적었다. 이
를 통해 대화차례가 주어졌을 때 말하는 발화의 빈도는 언어적 능 력에 영향을 받을 수 있다는 것을 알 수 있다. 대화차례 주고받기 빈 도와 대화차례당 발화 수 결과를 종합해 보았을 때, 학령기 아동은 학년이 높아질수록 대화차례를 더 많이 주고받기보다는 자신의 차 례에서 더 많은 발화로 대화를 이어나가는 경향을 보였다. 이는 대 화차례 주고받기 빈도보다는 대화차례당 발화 수가 언어능력뿐만 아니라 대화 참여 정도의 발달적 경향을 보여줄 수 있는 지표가 될 수 있음을 시사한다.

대화의 참여 지표와 더불어 대화 내에서 화제를 관리하는 능력 을 확인하기 위해 화제 수, 화제 유지 능력(화제당 대화차례 빈도, 화제 유지 비율), 화제 변경 비율로 나누어 살펴보았다. 그 결과 화 제 수, 화제당 대화차례 빈도, 화제 유지 비율, 화제 변경 비율 모두 에서 학년 집단 간 유의한 차이를 보였다. 화제 수는 아동이 새롭게 개시하는 화제의 경우에만 측정하는 것으로 얼마나 많은 화제로 이야기를 하는지 살펴볼 수 있지만, 중심 화제에서 벗어나는 화제 도 포함하여 측정하기 때문에 일관된 대화를 유지하지 못하는 경 우도 반영된다. 본 연구에서 화제 수는 1학년과 3학년 집단이 5학 년 집단에 비해 유의하게 높았는데, 이는 학년이 높아질수록 대화 내에서 다루어지는 화제 수가 더 적다는 것을 의미한다. Brinton과 Fujiki (1984)는 5세, 9세, 성인을 대상으로 화제관리능력을 살펴본 결과, 연령이 높아질수록 새로운 화제를 개시하는 경우가 적다는 것을 보고하였다. 본 연구 결과에서도 5 학년 집단이 1학년, 3 학년 집단에 비해 대화 내에서 다룬 화제 수가 더 적었는데, 이는 학령기 부터 성인기까지 연령이 증가할수록 대화 내에서 많은 화제를 다루 기 보다는 하나의 화제로 더 길게 대화를 한다는 것을 보여준다.

화제당 대화차례 빈도와 화제 유지 비율은 하나의 주제로 얼마 나 응집력있게 대화를 끌어나가는지를 반영하는 반면, 화제 변경 비율은 응집력있게 대화를 유지하지 못하는 것을 의미한다. 본 연 구에서 화제당 대화차례 빈도와 화제 유지 비율은 5 학년 집단이 1 학년과 3 학년 집단에 비해 유의하게 높은 반면, 화제 변경 비율은 1 학년과 3 학년 집단이 5 학년 집단에 비해 유의하게 높았다. 이는 학 년이 높아질수록 대화 내에서 하나의 주제로 주고받는 대화차례 
빈도가 증가하며, 응집력있게 화제를 유지하는 능력이 발달한다는 것을 의미한다. 3-6세 아동들의 화제관리능력을 살펴본 Park (2001) 은 본 연구 결과와 마찬가지로 연령이 증가할수록 한 화제당 대화 차례 빈도가 유의하게 더 많아짐을 보고하였으며, 5세, 9세, 성인을 대상으로 화제관리능력을 살펴본 Brinton과 Fujiki (1984)는 어린 아동일수록 대화 화제 간에 전환이 빨리 이루어지고, 화제 변경이 더 많이 발생하여 하나의 화제로 일관된 대화를 이어나가지 못한 다고 보고하였다. 따라서 학령전기 시기부터 학령기 시기를 지나 성 인기까지 연령이 증가할수록 하나의 화제로 주고받는 대화차례 빈 도가 증가한다고 해석할 수 있다.

화제를 유지하더라도 연령이 낮을수록 이전 대화를 반복하거나 형식만을 변경하며 유지해나가고, 연령이 높아질수록 새로운 정보 를 첨가하거나 확장하며 더 정교하게 화제를 유지해나간다(Brinton \& Fujiki, 1984; Schober-Peterson, 1993; Mentis, 1994; Sehley \& Snow, 1992). Kertoy와 Vetter (1995)는 이전 발화에 새로운 정보를 첨가해나가며 유지해나가기 위해서는 이전 발화를 완전히 이해한 후 관련된 새로운 정보를 첨가해야 한다고 하였다. 이러한 과정은 언어적, 인지적 부담이 크기 때문에, 연령이 낮을수록 새로운 정보 없이 화제를 유지해 나가는 경향이 나타날 가능성이 있다고 해석 할 수 있다. 본 연구에서 화제 유지는 아동의 화제관리능력의 발달 을 잘 보여주는 지표임을 확인하였다. Choi와 Lee (2015)는 자페스 펙트럼장애 아동의 화제 유지 능력을 더 확장시켜 수반성과 정보성 을 중심으로 살펴보았는데, 자폐스펙트럼장애 아동의 경우 대화 시 화제를 유지하는 수반성뿐만 아니라 유지된 발화 안에서도 정 보를 포함하여 화제를 확장시키는 것에 어려움을 보이는 것으로 나 타났다. 이처럼 화제 유지 능력을 정보성과 수반성을 중심으로 일 반아동의 발달적 경향을 살펴본다면 언어장애 아동들의 화제 유 지 능력에 주는 임상적 시사점을 찾을 수 있을 것으로 생각된다. 화 제관리능력의 결과를 종합해 보았을 때, 학년이 증가할수록 새로 운 화제로 변경하기 보다는 하나의 화제를 길게 유지하며 일관된 대화를 이끌어나간다는 것을 보여주었다.

본 연구 결과를 종합해 보면, 대화 절차 내에서 연령이 증가할수 록 대화차례당 더 많은 발화로 말하며, 대화 내에서 다루는 화제 수 는 적어지지만, 하나의 화제로 많은 정보를 주고받을 수 있다는 것 을 보여주었다. 또한 연령이 증가할수록 다른 화제로의 변경이 점 차 안정되어 하나의 화제를 일관되게 유지해 나가며 대화를 이어나 간다는 것을 알 수 있었다. 본 연구는 대화를 중심으로 학령기 아동 의 대화 발달을 살펴보았으며, 대화의 여러 측정치들 중 발달을 보 여줄 수 있는 측정치를 알아보았다는 점에서 의의가 있다. 본 연구 에서 각 집단별로 포함된 아동은 10 명으로 대상자가 적었으나, 초
등학생 대화의 발달적 경향을 이해하는 데 도움을 주고, 이후 장애 아동의 대화 평가 및 중재에 필요한 자료로 제시될 수 있음을 시사 해준다. 이후 연구에서는 앞서 언급한 것처럼 일반아동의 화제 유지 능력을 수반성과 정보성을 중심으로 살펴볼 필요가 있다.

\section{REFERENCES}

Adams, C., \& Bishop, D. V. M. (1989). Conversational characteristics of children with semantic-pragmatic disorder: exchange structure, turntaking, repairs and cohesion. British Journal of Disorders of Communication, 24, 211-239.

Baines, E., \& Howe, C. (2010). Discourse topic management and discussion skills in middle childhood: the effects of age and task. First Language, 30, 508-534.

Bishop, D., Chan, J., Hartley, J., \& Weir, F. (2000). Conversational responsiveness in specific language impairment. Development and Psychopathology, 12, 177-199.

Brinton, B., \& Fujiki, M. (1984). Development of topic manipulation skills in discourse. Journal of Speech, Language, and Hearing Research, 27, 350-358.

Brinton, B., Fujiki, M., \& Powell, J. M. (1997). The ability of children with language impairment to manipulate topic in a structured task. Language, Speech, and Hearing Services in Schools, 28, 3-11.

Bryan, T., Donahue, M., Pearl, R., \& Sturm, C. (1981). Learning disabled children's conversational skills: the 'TV Talk Show'. Learning Disability Quarterly, 4, 250-259.

Choi, J., \& Lee, Y. (2013). Conversational turn-taking and topic manipulation skills of children with high-functioning autism spectrum disorders. Communication Sciences \& Disorders, 18, 12-23.

Choi, J., \& Lee, Y. (2015). Contingency and informativeness of topic maintenance in children with high-functioning autism spectrum disorders. Communication Sciences \& Disorders, 20, 413-423.

Choi, Y. M., \& Jeon, B. U. (2013). An analysis of turn-taking of children with mental retardation. Communication Sciences \& Disorders, 8, 82-96.

Crystal, D., Fletcher, P., \& Garman, M. (1976). The grammatical analysis of language disability: a procedure for assessment and remediation. London: Edward Arnold.

Dorval, B., Eckerman, C. O., \& Ervin-Tripp, S. (1984). Developmental trends in the quality of conversation achieved by small groups of acquainted peers. Monographs of the Society for Research in Child Development, 49, 1-91.

Evans, J. L., \& Craig, H. K. (1992). Language sample collection and analysis: 
interview compared to freeplay assessment contexts. Journal of Speech, Language, and Hearing Research, 35, 343-353.

Foster, S. (1985). The development of discourse topic skills by infants and young children. Topics in Language Disorders, 5, 31-45.

Heo, H., \& Lee, Y. (2012). Conversational turn-taking and topic manipulation skills in conversations of school-age low-achievers in language learning. Korean Journal of Communication Disorders, 17, 66-78.

Hoff, E. (2009). Language development (5th ed.). Belmont, CA: Wadsworth Publishing.

Hong, J. S., Heo, H., \& Lee, Y. (2012). Turn-taking characteristics of children with cochlear implant (CI). Journal of Speech \& Hearing Disorders, 21, $243-$ 259.

Hong, U., \& Lee, Y. (2016). Conversational characteristics of children with a mild intellectual disability. Special Education Research, 15, 111-126.

Keenan, E. O., \& Klein, E. (1975). Coherency in children's discourse. Journal of Psycholinguistic Research, 4, 365-380.

Kertoy, M. K., \& Vetter, D. K. (1995). The effect of conversational setting on topic continuation in mother-child dyads. Journal of Child Language, 22, 73-88.

Kim, Y. T. (1997). Study of MLU in Korean 2-4 years children. Korean Journal of Communication Disorders, 2, 5-25.

Kim, S. E., \& Lee, Y. (2007). Conversation characteristics of children with attention deficit hyperactivity disorder. Korean Journal of Communication Disorders, 12, 662-675.

Lee, H. J., \& Kim, Y. T. (2001). Turn-taking characteristics of children with specific language impairment and normal children. Korean Journal of Communication Disorders, 6, 293-312.
Lee, Y., \& Choi, J. (2017). Hallym Conversation and Pragmatic Assessment Protocol. Manuscript in preparation.

Lee, Y., Heo, H., \& Jhang, S. (2015). Language Scale for School-aged Children (LSSC). Seoul: Hakjisa.

Mentis, M. (1994). Topic management in discourse: assessment and intervention. Topics in Language Disorders, 14, 29-54.

Nippold, M. A. (2007). Later language development: school-age children, adolescents, and young adults (3rd ed.). Austin, TX: Pro-Ed.

Owens, R. E. (2004). Language disorder: a functional approach to assessment and intervention (4th ed.). Boston, MA: Allyn \& Bacon.

Park, E. (2001). Development of topic management of Korean-Speaking children aged 3-6 years (Master's thesis). Ewha Womans University, Seoul, Korea.

Prutting, C. A., \& Kittchner, D. M. (1987). A clinical appraisal of the pragmatic aspects of language. Journal of Speech and hearing Disorders, 52, 105-119.

Rosenthal, M. (1982). Vocal dialogues in the neonatal period. Developmental Psychology, 18, 17-21.

Schober-Peterson, D., \& Johnson, C. J. (1989). Conversational topics of 4-yearolds. Journal of Speech, Language, and Hearing Research, 32, 857-870.

Schober-Peterson, D., \& Johnson, C. J. (1993). The performance of eight-to ten-year-olds on measures of conversational skilfulness. First Language, 13, 249-269.

Sehley, S., \& Snow, C. (1992). The conversational skills of school-aged children. Social Development, 1, 18-35.

Stech, E. L. (1982). The analysis of conversational topic sequence structures. Semiotica, 39, 75-92.

Weiner, S. L., \& Goodenough, D. R. (1977). A move toward a psychology of conversation. Discourse Production and Comprehension, 1, 213-224. 
Appendix 1. 대화차례 정의 및 세부적인 구분원칙

\begin{tabular}{|c|c|}
\hline 구분 & 예 \\
\hline $\begin{array}{l}\text { 1. 대화차례는 화자가 말을 시작하여 대화상대자가 말을 시작하기 전까지 동일한 } \\
\text { 화자가 이어간 모든 발화를 의미한다(Adams \& Bishop, 1989; Bishop, Chan, } \\
\text { Hartley, \& Weir, 2000; Bryan, Donahue, Pearl, \& Sturm, 1981; Kim \& Lee, } \\
\text { 2007). }\end{array}$ & $\begin{array}{l}\text { 검: 주말에는 가족들이랑 뭐하면서 보내? } \\
\text { 아: 토요일 날엔 놀러도 많이 가고 친척동생이랑 삼촌도 보러 가요. (대화차례 1) } \\
\text { 검: 토요일에 놀러도 가고 친척들 보러가는 구나." }\end{array}$ \\
\hline $\begin{array}{l}\text { 2. 아동이 자신이 말 차례에 대화 화제를 변경하는 경우 대화차례를 나눈다(Kim \& } \\
\text { Lee, 2007; Schober-Peterson \& Johnson, 1989). }\end{array}$ & $\begin{array}{l}\text { 성인: “쉬는 시간에는 뭐해?” } \\
\text { 아동: “쉬는 시간에는 친구들이랑 이야기하면서 놀고요.” (대화차례 1) } \\
\text { 아동: “점심시간에는 친구들이랑 나가서 축구해요." (대화차례 2) }\end{array}$ \\
\hline $\begin{array}{l}\text { 3. 동일한 화제로 대화차례를 이어나갈 때, 발화 중에 3초이상 쉼이 나타나는 경우 } \\
\text { 에는 서로 다른 대화차례로 구분한다(Kim \& Lee, 2007; Lee \& Kim, 2001). }\end{array}$ & $\begin{array}{l}\text { 성인: “요즘 너랑 친구들은 뭐를 좋아해?” } \\
\text { 아동: “좋아하는 거는 게임 좋아하구요.(3")" (대화차례 1) } \\
\text { 아동: “친구들이랑 좋아하는 거는 딱히 없는 것 같은데." (대화차례 2) }\end{array}$ \\
\hline $\begin{array}{l}\text { 4. 아동이 자신의 대화차례에서 맞장구(back channel responses) 등의 낱말이나 } \\
\text { 구로 말한 경우에도 하나의 대화차례로 인정한다(Crystal, Fletcher, \& Garman, } \\
\text { 1976). }\end{array}$ & $\begin{array}{l}\text { 아동: "아빠랑 낚시하러 갔었어요." (대화차례 1) } \\
\text { 성인: "아빠랑 낚시하러 갔었구나." } \\
\text { 아동: "맞아요” (대화차례 2) }\end{array}$ \\
\hline $\begin{array}{l}\text { 5. 아동이 단순히 상대방의 말을 듣고 있다는 추임새로서 머리 끄덕이기, 고개 젓 } \\
\text { 기, 가리키기 등의 비구어적 행동은 대화차례로 보지 않으나, 대화 상대방의 질 } \\
\text { 문이나 지시에 자연스럽게 상대방에게 대화차례를 넘기는 기능(turn passing- } \\
\text { move function)을 가지는 발성 및 행동의 경우에는 하나의 대화차례로 간주한 } \\
\text { 다 (Adams \& Bishop, 1989; Bishop et al., 2000; Weiner \& Goodenough, } \\
\text { 1977). }\end{array}$ & $\begin{array}{l}\text { 아동: “학교 끝나고 방과후에는 탁구도하고 옹기종기 도자기도 해요." (대화차례 1) } \\
\text { 성인: “방과후에 탁구도 하고 옹기종기 도자기도 하는구나. (3초 후) 그리고?” } \\
\text { 아동: (고개를 가로로 저음) (대화차례 2) } \\
\text { 성인: “더 이상 없구나, 알겠어.” }\end{array}$ \\
\hline
\end{tabular}

출처: Heo \& Lee (2012) 재수정.

Appendix 2. 화제 정의 및 세부 구분 원칙

화제란 화자가 발화를 통해 제공하는 주요 정보(Owens, 2004)로, 하나의 발화 또는 동일한 어휘, 주제어(theme), 개념(concept) 또는 구성요소로 서로 연관된 일련의 발화로 제공될 수 있다(Schober-Peterson \& Johnson, 1993).

\begin{tabular}{|c|c|}
\hline 기준 & 예시 \\
\hline $\begin{array}{l}\text { 1. 새롭게 화제가 개시된 후 새로운 화제로 변경되기 전까지 이어진 발화 } \\
\text { 는 하나의 화제로 측정한다. }\end{array}$ & $\begin{array}{l}\text { 아동: “저번에 저희가 팔자 줄넘기를 잘 못해요. 그래가지고 선생님한테 혼나서 연습을 많이 } \\
\text { 했어요." (팔자줄넘기 화제 소개) - 화제 수 포함 } \\
\text { 성인: "선생님한테 혼나서 연습을 많이 했구나.” }\end{array}$ \\
\hline $\begin{array}{l}\text { 2. 이미 언급된 화제에 대해 정교화하거나 내용을 첨가하는 경우에는 } \\
\text { 별도의 화제로 측정하지 않는다. }\end{array}$ & $\begin{array}{l}\text { 아동: “그래서 꼴찌였다가 4등이 되었어요.” (정교화 및 내용 첨가) - 화제 수 포함 안 함 } \\
\text { 성인: “아, 꼴찌였다가 4등이 되었구나.” } \\
\text { 아동: “그리고 급식시간에 급식을 먹는데, 여기 오기 전에 양구 급식이 더 맛있었어요.” } \\
\quad \text { (급식 화제 변경) - 화제 수 포함 }\end{array}$ \\
\hline $\begin{array}{l}\text { 3. 하나의 화제가 종료되고 다른 화제로 변경되었다가 다시 이전 화제로 } \\
\text { 언급한 경우에도 새로운 화제로 측정하지 않는다. }\end{array}$ & $\begin{array}{l}\text { 성인: 아, 양구 급식이 더 맛있구나.” } \\
\text { 아동: “팔자 줄넘기할 때요. 선생님이 자세를 많이 고치라고 했는데 고쳐가지고 선생님이 } \\
\quad \text { 많이 칭찬 해 주셨어요. (이전 화제 다시 언급) - 화제 수 포함 안 함 }\end{array}$ \\
\hline
\end{tabular}

출처: Schober-Peterson \& Johnson (1993) 수정 및 보완. 
Appendix 3. 화제관리능력의 유형(유지, 변경)별 정의 및 예시

\begin{tabular}{|c|c|c|}
\hline 구분 & 정의 & 예시 \\
\hline 화제유지 & $\begin{array}{l}\text { 이전 대화차례에서 개시된 화제와 관련된 내용을 반복, } \\
\text { 간단한 정보 또는 세밀한 의미를 추가하면서 대화차 } \\
\text { 례를 이어나가는 경우이다(Brinton \& Fujiki, 1984; } \\
\text { Mentis, 1994; Prutting \& Kittchner, 1987). } \\
\text { (1) 어휘로 연결된 경우 } \\
\text { (2) 주제(theme)로 연결된 경우 } \\
\text { (3) 개념(concept)이나 구성요소로 연결된 경우 }\end{array}$ & $\begin{array}{l}\text { (1) 성인: "요즘에 너랑 친구들은 뭘 좋아해? } \\
\text { 아동: "노는 거랑 술래잡기 좋아해요." } \\
\text { 성인: “노는 거랑 술래잡기 좋아하는구나." } \\
\text { 아동: "도서관 가는 것도 좋아하고요. 모둠 친구들이랑 함께하는 것도 좋아해요." } \\
\text { (2) 성인: “TV 프로그램에서 재밌는 거는 뭐야? } \\
\text { 아동: "포켓몬스터요." } \\
\text { 성인: "포켓몬스터." } \\
\text { 아동: “그리고 드래곤 빌리지요." } \\
\text { 성인: “드래곤빌리지” } \\
\text { 아동: "터닝메카드요." } \\
\text { (3) 성인: “TV 프로그램에서 재미있는 거는 뭐야? } \\
\text { 아동: "저는 뮤직뱅크가 매일 좋아요." } \\
\text { 성인: "뮤직뱅크가 제일 좋구나." } \\
\text { 아동: "많이 보지는 않지만 유투브를 보는데 저는 트와이스를 좋아해가지고 그걸 보는데 한번 } \\
\quad \text { 가보고 싶다는 생각을 했어요." }\end{array}$ \\
\hline 화제변경 & $\begin{array}{l}\text { 화제 변경은 대화를 이어나가는 도중 이전 대화차례의 } \\
\text { 화제와 연결되지 않거나 자신의 이전 발화에서 새로 } \\
\text { 운 화제로 대화 화제가 바뀌는 경우이다 (Brinton \& } \\
\text { Fujiki, 1984; Mentis, 1994; Prutting \& Kittchner, } \\
\text { 1987). }\end{array}$ & $\begin{array}{l}\text { 아동: “저희 반 학예회 때 리코더 연주했어요.” “저는 리코더를 잘 못 불었는데, 선생님이 가르쳐 주 } \\
\quad \text { 셔서 리코더에도 재미가 들렸어요.” } \\
\text { 성인: “선생님이 가르쳐주셔서 재미가 들렸구나.” } \\
\text { 아동: “급식시간은 제가 가장 기대되는 시간이에요.” ('리코더’ 화제에서 ‘급식시간으로 화제 변경) }\end{array}$ \\
\hline
\end{tabular}

출처: Choi \& Lee (2013) 재수정. 


\section{국문초록}

\section{초등학생 아동의 대화 화제관리 능력의 발달}

박윤정' 최지은 $\cdot$ 이윤경

'한림대학교 대학원 언어병리청각학과, ${ }^{2}$ 한림대학교 언어청각학부

배경 및 목적: 대화는 학령기 아동들의 또래 관계 형성 및 학업 성취 등의 사회적인 측면에 중요한 역할을 한다. 본 연구는 초등학생을 대상으로 대화에 참여하는 정도와 화제를 관리하는 능력의 발달적 차이를 살펴보고자 하였다. 방법: 연구 대상은 1 학년, 3 학년, 5 학년 아동 각 10 명씩 총 30 명이었다. 모든 아동에게 함림 대화·화용 평가 프로토콜에 따라 대화 자료를 수집한 후, 대화 참여 지표인 대화차 례 주고받기 빈도와 대화차례당 발화 수를 측정하였고, 화제 지표인 전체 화제 수, 화제당 대화차례 빈도, 화제 유지 비율, 화제 변경 비 율을 측정하였다. 결과: 대화 참여 지표에서 대화차례당 발화 수는 집단 간 유의한 차이가 있었으나 대화차례 주고받기 빈도는 유의한 차이가 없었다. 화제 지표에서 전체 화제 수, 화제당 대화차례 빈도, 화제 유지 비율, 화제 변경 비율 모두 학년 집단 간 유의한 차이가 나 타났다. 논의 및 결론: 초등학생은 대화에 참여하고 화제를 관리하는 능력이 학년에 따라 달라졌다. 학년이 높아질수록 자신의 대화차 례에서 동일한 화제에 대해 더 많은 발화를 산출하고, 화제를 일관되게 유지할 수 있다는 것을 보여주었다. 이러한 결과는 초등학생의 대화 발달을 이해하는데 도움을 주고, 이후 장애아동의 대화 평가 및 중재에 필요한 자료로 활용될 수 있음을 시사해준다.

핵심어: 학령기, 대화 발달, 주제운용, 화제관리

본 논문은 제1저자의 석사학위논문(2017)를 수정·보완한 것임.

\section{참고문헌}

김성은, 이윤경(2007). 주의력결핍 과잉행동장애 (ADHD) 아동의 말차례 주고받기 특성. 언어청각장애연구, 12, 662-675.

김영태(1997). 한국 2-4세 아동의 발화길이에 관한 기초 연구. 언어청각장애연구, 2, 5-25.

박은정(2001).3-6세 아동의 또래친구간 대화에서의 화제관리능력 연구. 이화여자대학교 석사학위논문.

이윤경, 최지은(2017). 한림 대화·화용 평가 프로토콜. 출판예정.

이윤경, 허현숙, 장승민(2015). 학령기 아동 언어검사. 서울: 학지사.

이효진, 김영태(2001). 단순언어장애 아동의 대화 말차례 특성. 언어청각장애연구, 6, 293-312.

최지은, 이윤경(2013). 학령기 고기능 자폐범주성장애 아동의 대화차례 주고받기 및 주제운용능력. 언어청각장애연구, 18, 12-23.

최지은, 이윤경(2015). 학령기 고기능 자폐스펙트럼장애 아동의 주제유지능력: 수반성과 정보성을 중심으로. 언어청각장애연구, 20, 413-423.

최유미, 전병운(2003). 정신지체 아동과 일반아동의 말주고받기 특성 비교 연구. 언어청각장애연구, 8, 82-96.

허현숙, 이윤경(2012). 언어학습부진아동의 대화차례 주고받기 및 주제운용 특성. 언어청각장애연구, 17, 66-78.

홍욱표, 이윤경(2016). 경도지적장애아동의 대화특성. 특수교육, 15, 111-126.

홍지숙, 허현숙, 이윤경(2012). 초등 저학년 인공와우이식 (CI) 아동의 대화차례 주고받기 특성. 언어치료연구, 21, 243-259. 